\title{
Keanekaragaman Arthropoda pada lahan pertanian kacang di Kabupaten Kupang Provinsi Nusa Tenggara Timur
}

\author{
Arthropods diversity on pea's field in Kupang Regency East Nusa Tenggara Province
}

\author{
Chatarina Gradict Semiun *, Yulita Iryani Mamulak \\ Program Studi Biologi, Fakultas Matematika dan Ilmu Pengetahuan Alam, Universitas Katolik Widya Mandira \\ Jl. A. Yani No 50-52 Kupang, Indonesia - 85225 \\ *Email: chatarinagr4dict@unwira.ac.id
}

Diterima 14 Januari 2021 Disetujui 15 Pebruari 2021

\section{INTISARI}

Keberhasilan budi daya tanaman kacang-kacangan dipengaruhi oleh keberadaan Arthropoda yang berperan sebagai polinator, dekomposer, parasitoid, dan bioindikator. Tujuan penelitian ini untuk menentukan keanekaragaman Arthropoda pada lahan pertanian kacang-kacangan di Kabupaten Kupang. Penelitian ini bersifat deskriptif kuantitatif yang telah dilaksanakan di tiga lokasi, yaitu lahan kacang tanah, lahan kacang panjang, dan lahan kacang hijau. Pengambilan sampel Arthropoda menggunakan pitfall trap, insect net, dan hand sorting. Hasil penelitian ditemukan keanekaragaman Arthropoda yang bervariasi di tiga lahan pertanian kacang. Pada lahan pertanian kacang tanah ditemukan 31 spesies, 15 famili, 9 ordo, 2 kelas, dengan total individu 115. Pada lahan pertanian kacang panjang ditemukan 17 spesies, 11 famili, 7 ordo, 2 kelas, dengan total individu 53. Pada lahan pertanian kacang hijau ditemukan 30 spesies, 20 famili, 9 ordo, 3 kelas, dengan total individu 108. Indeks keanekaragaman tertinggi terdapat pada lahan pertanian kacang hijau sebesar 3.19, diikuti lahan kacang tanah sebesar 2.83, dan lahan kacang panjang sebesar 2.43. Nilai indeks kekayaan jenis tertinggi terdapat pada lahan kacang tanah sebesar 6.32 diikuti lahan kacang hijau sebesar 6.19, dan terendah lahan kacang panjang sebesar 4.03. Tidak ada jenis Arthropoda yang mendominasi di ketiga lahan pertanian kacang dengan kemerataan jenis tergolong merata penyebarannya. Kesamaan Jaccard antar habitat kacang menunjukkan nilai lebih kecil dari 50\%, artinya tingkat kesamaan famili Arthropoda yang ditemukan di ketiga habitat kacang tergolong rendah. Tingkat kesamaan yang rendah dapat disebabkan oleh aplikasi pestisida khususnya pada lahan kacang panjang dan kacang hijau. Selanjutnya, faktor abiotik memberikan pengaruh yang signifikan terhadap keanekaragaman arthropoda.

Kata kunci: kacang hijau, kacang panjang, kacang tanah, keanekaragaman Arthropoda

\begin{abstract}
The success of pea's cultivation is influenced by the presence of arthropods that act as pollinators, decomposers, parasitoids and bioindicators. This research aimed at determining the diversity of arthropods on pea's farming lands in Kupang district. This research was a descriptive quantitative research that had been carried out in three locations, namely peanut farming field, long bean farming field, and green bean farming field. Arthropod samples were taken by using pitfall traps, insect nets, and hand sorting. The results showed that arthropod diversity varied in the three pea's farming lands. First, on peanut farming land, 31 species, 15 families, 9 orders, 2 classes were found, with a total of 115 individuals. Second, on the long bean farming land, 17 species, 11 families, 7 orders, 2 classes were found, with a total of 53 individuals. Last, there were 30 species, 20 families, 9 orders, 3 classes, with a total of 108 individuals found in green
\end{abstract}


bean farming land. The highest diversity index was found in green bean farming land at 3.19, followed by peanut farming land at 2.83, and long bean farming land at 2.43. The highest species richness index value was found in peanut farming land at 6.32, followed by green bean farming land at 6.19 , and the lowest in long bean farming land at 4.03. There was no arthropod species that dominated in the three peanut farming lands, the species were classified as evenly distributed. The similarity between Jaccard and peanut habitats showed a value less than $50 \%$, meaning that the similarity level of the arthropod family found in the three pea habitats was low. The low level of similarity could be caused by the application of pesticides, especially in long beans and green beans farming lands. Furthermore, abiotic factors had a significant effect on arthropod diversity.

Keywords: Arthropod diversity, green beans, long beans, peanuts

\section{PENDAHULUAN}

Kacang-kacangan merupakan salah satu tanaman komoditi di Nusa Tenggara Timur, yang bernilai gizi tinggi dan merupakan salah satu tanaman untuk meningkatkan kebutuhan ekonomi masyarakat di Kabupaten Kupang. Oleh karena itu, budi daya tanaman kacang terus dikembangkan oleh para petani. Budi daya tanaman kacang ini dipengaruhi oleh faktor abiotik dan biotik. Faktor abiotik seperti $\mathrm{pH}$ tanah, suhu, intensitas cahaya, nutrisi, water holding capacity, dan berat jenis tanah (Semiun \& Mamulak 2019). Sedangkan faktor biotik meliputi semua makhluk hidup salah satunya keberadaan arthropoda.

Arthropoda merupakan hewan yang memiliki fungsi ekologis yang sangat penting bagi ekosistem. Fungsi ekologis tersebut diantaranya sebagai polinator, predator dan parasitoid (Ardillah et al. 2014). Culliney (2013) menambahkan Arthropoda dapat meningkatkan porositas tanah untuk menyediakan aerasi dan kapasitas penampung air di bawah tanah; memfasilitasi penetrasi akar, dan mencegah pengerasan permukaan dan erosi tanah; dan kotoran arthropoda adalah dasar pembentukan agregat tanah dan humus. Fungsi ekologis yang penting lainnya adalah sebagai bioindikator dalam menilai kualitas lingkungan (Semiun et al. 2020). Sebagai bioindikator Arthropoda dapat dijadikan alat pendeteksi perubahan yang terjadi di lingkungan sehingga saintis dapat memprediksi level ganguan di lingkungan tersebut (Parmar et al. 2016).
Kebanyakan masyarakat menganggap keberadaan Arthropoda tidak memberikan dampak positif terhadap hasil pertanian mereka. Arthropoda sering dianggap sebagai hama yang merusak lahan pertanian. Kurangnya pemahaman masyarakat tentang peranan Arthropoda di lahan pertanian kacang mendorong kami untuk melakukan penelitian ini. Tujuan penelitian ini untuk menentukan keanekaragaman arthropoda pada lahan pertanian kacang-kacangan yang ada di Kabupaten Kupang Nusa Tenggara Timur.

\section{MATERI DAN METODE}

\section{Tempat dan waktu penelitian}

Penelitian dilaksanakan dari bulan Maret sampai Desember 2019. Berdasarkan survei lapangan dipilih tiga kecamatan yang ada di Kabupaten Kupang, yaitu Kupang Barat - Desa Oematnunu (lahan pertanian kacang tanah), Kupang Tengah- Desa Mata Air (lahan pertanian kacang panjang), dan Kupang Timur - Desa Manusak (Lahan pertanian kacang hijau) (Gambar 1.).

\section{Bahan dan alat}

Bahan yang digunakan dalam penelitian ini adalah alkohol $70 \%$ untuk menarik arthropoda masuk ke jabakan, detergen untuk mematikan Arthropoda yang masuk ke dalam perangkap, dan sampel tanah untuk menganalisis faktor abiotik seperti water holding capacity (WHC) dan berat jenis tanah. Selanjutnya, alat yang digunakan dalam penelitian ini meliputi: GPS untuk menentukan titik koordinat dan elevasi lokasi, 
digital soil tester meter 4 in 1 untuk mengukur $\mathrm{pH}$ tanah, suhu tanah, intensitas cahaya, dan kelembaban tanah; roll meter $(100 \mathrm{~m})$ untuk mengukur panjang dan interval petak pengamatan, plastik aqua gelas sebagai wadah untuk menjebak Arthropoda, saringan dari kain putih transparan untuk memisahkan Arthropoda dengan larutan perangkap, botol sampel untuk menyimpan sampel, insect net untuk menangkap Arthropoda yang aktif terbang.

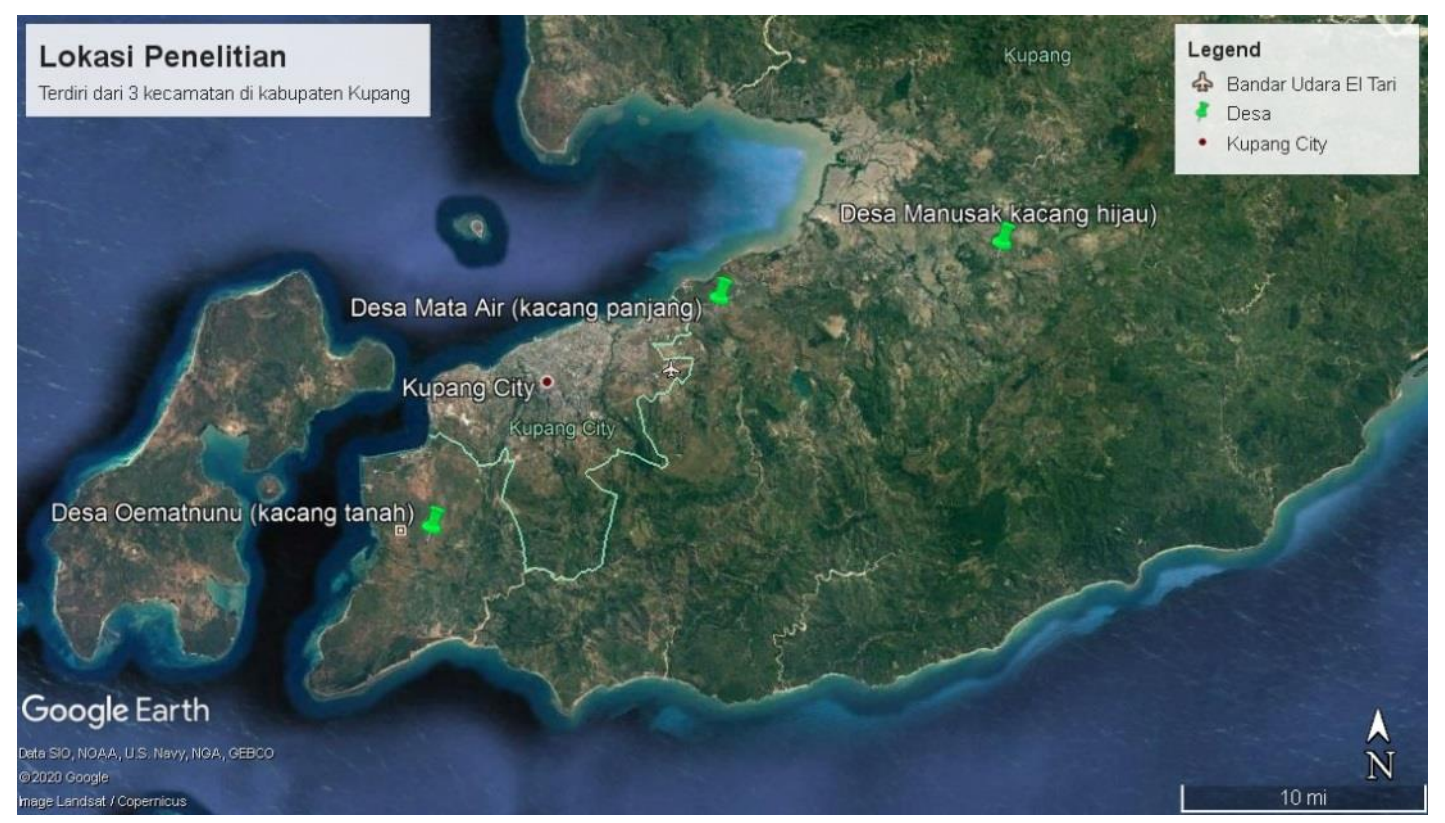

Gambar 1. Lokasi penelitian

\section{Metode}

Pengambilan dan identifikasi sampel Arthropoda

Pengambilan sampel dilakukan dengan terlebih dahulu membuat plot. Penentuan plot secara sistematik acak. Setiap lahan diberikan lima plot dengan jarak antar plot lima meter. Setiap plot dipasangkan pitfall trap di tiga titik secara diagonal. Selain itu, peneliti juga melakukan pengambilan sampel Arthropoda secara aktif dengan menggunakan jaring serangga (insect net) dan tangan (hand sorting).

Arthropoda yang telah diperoleh selanjutnya diidentifikasi menggunakan buku panduan seperti A Field Guide to Insects (Borror et al. 1970); Pengenalan Pelajaran Serangga (Borror et al. 1996); Hymenoptera of the World: an Identification Guide to Families (Goulet, 1993); dan Kunci determinasi serangga (Siwi 2006). Proses identifikasi juga dilakukan dengan cara browsing internet pada website terkait seperti group.insectidentification, dan www.bugguide.net yang dikelola oleh Iowa State University Entomology.

Pengukuran faktor lingkungan.

Pengukuaran faktor abiotik dilakukan secara langsung di lapangan dan secara tidak langsung dengan membawa sampel tanah ke laboratorium. Faktor abiotik yang diukur secara langsung meliputi pH tanah, suhu tanah, suhu udara, kelembaban tanah, intensitas cahaya, dan elevasi. Faktor abiotik yang diukur secara tidak langsung adalah berat jenis tanah dan water holding capacity (WHC).

\section{Analisis data}

Data hasil identifikasi ditabulasi menggunakan open source MS. Exel 2010. Data-data tersebut selanjutnya dianalisis untuk mencari indeks diversitas (Elhayati et al. 2017), indeks kekayaan jenis (Amin et al. 2016), indeks dominansi (Ludwig \& Reynold 1998), indeks kemerataan jenis (Semiun et al. 2020), dan indeks kesamaan jenis Jaccard (Haneda et al. 2013). Penghitungan 
indeks Jaccard merujuk pda famili Arthropoda yang ditemukan. Pengaruh faktor abiotik terhadap keanekaragaman Arthropoda ditentukan dengan analisis uji regresi linear berganda. Analisis ini difasilitasi dengan open source software SPSS 19.00 .

\section{HASIL}

Tabel 1 menunjukan spesies Arthopoda yang ditemukan diketiga lahan pertanian kacang. Pada lahan pertanian kacang tanah ditemukan 31 spesies, 15 famili, 9 ordo, 2 kelas, dengan total individu 115. Orthoptera merupakan ordo dengan jumlah famili dan spesies ditemukan terbanyak yaitu 3 famili dan 13 spesies. Pada lahan pertanian kacang panjang ditemukan 17 spesies, 11 famili, 7 ordo, 2 kelas, dengan total individu 53. Hymenoptera merupakan ordo dengan jumlah spesies terbanyak yaitu 5 spesies. Pada lahan pertanian kacang hijau ditemukan 30 spesies, 20 famili, 9 ordo, 3 kelas, dengan total individu 108. Selain itu, didapati kelas diplopoda yang tidak ditemukan di dua lahan pertanian kacang lainnya.

Tabel 1. Jenis arthropoda di lahan pertanian kacang tanah, kacang panjang, dan kacang hijau di Kabupaen Kupang

\begin{tabular}{|c|c|c|c|c|c|c|}
\hline \multirow{2}{*}{ Kelas } & \multirow{2}{*}{ Ordo } & \multirow{2}{*}{ Famili } & \multirow{2}{*}{ Spesies } & \multicolumn{3}{|c|}{$\sum$ Individu } \\
\hline & & & & $\mathbf{K N}$ & $\mathbf{K P}$ & KH \\
\hline \multirow[t]{32}{*}{ Insekta } & Hymenoptera & Formicidae & Myrmica rubra & 26 & - & 9 \\
\hline & & & Camponotus herculeanus & 15 & - & - \\
\hline & & & Solenopsis invicta & 1 & - & - \\
\hline & & & Solenopsis richteri & 1 & - & - \\
\hline & & & Solenopsis molesta & - & - & 2 \\
\hline & & & Camponotus nearcticus & 1 & - & - \\
\hline & & & Camponotus sp. & - & - & 6 \\
\hline & & & Solenopsis sp. & - & 12 & - \\
\hline & & & Iridomyrmex anceps & - & 7 & 3 \\
\hline & & & Formica sp. & - & 9 & - \\
\hline & & & Stenamma sp. & - & 1 & - \\
\hline & & & Platythyrea sp. & - & 2 & - \\
\hline & & Vespidae & Ropalidia fasciata & - & - & 1 \\
\hline & & Apidae & Apis andreniformis & - & - & 2 \\
\hline & Mantodea & Mantidae & Tenodera sinensis & - & 1 & - \\
\hline & & & & - & 1 & - \\
\hline & Orthoptera & Gryillidae & Gryllus assimilis & 3 & - & - \\
\hline & & & Gryllus pennsylvanicus & 3 & - & - \\
\hline & & & Gryllus bimaculatus & 1 & - & - \\
\hline & & & Gryllus sp. & 10 & - & - \\
\hline & & & Gryllus assimilis & 1 & - & - \\
\hline & & Acrididae & Valanga sp. & 2 & - & - \\
\hline & & & Valanga nigricornis & 1 & - & - \\
\hline & & & Locusta migratoria & 3 & - & 3 \\
\hline & & & Xenocatantops humilis & 2 & - & 5 \\
\hline & & & Xenocatantops sp. & 1 & - & - \\
\hline & & & Melanoplus cinereus & 2 & - & - \\
\hline & & & Dissosteira sp. & 4 & - & - \\
\hline & & & Dissosteira carolina & - & - & 3 \\
\hline & & Tettigoniidae & Scudderia sp. & 10 & - & 2 \\
\hline & & Pyrgomorphidae & Atractomorpha crenulata & - & - & 11 \\
\hline & & & Atractomorpha sinensis & - & - & 4 \\
\hline
\end{tabular}




\begin{tabular}{|c|c|c|c|c|c|c|}
\hline & \multirow{3}{*}{ Hemiptera } & \multirow[b]{2}{*}{ Coreidae } & \multirow{2}{*}{$\begin{array}{l}\text { Atractomorpha sp. } \\
\text { Coreus maarginatus }\end{array}$} & \multirow{2}{*}{-} & \multirow{2}{*}{ - } & \multirow{2}{*}{$\begin{array}{l}2 \\
2\end{array}$} \\
\hline & & & & & & \\
\hline & & & Mictis profana & 1 & - & - \\
\hline & & & Anasa sp. & - & 1 & - \\
\hline & & & Leptocorisa acuta & - & 4 & - \\
\hline & & Alydidae & Alydus sp. & 6 & - & - \\
\hline & & & Riptortus linearis & - & - & 10 \\
\hline & & Lygaeidae & Neacoryphus bicrucis & - & 3 & - \\
\hline & & Pentatomidae & Nezara viridula & - & - & 3 \\
\hline & \multirow[t]{5}{*}{ Lepidoptera } & Pieridae & Eurema brigitta & 4 & - & - \\
\hline & & & Eurema hecabe & 1 & - & - \\
\hline & & & Eurema sp. & - & - & 2 \\
\hline & & Nymphalidae & Melanitis phedima & 1 & - & - \\
\hline & & Papilionidae & Hypermnestra sp. & - & 1 & - \\
\hline & Mantodea & Mantidae & Hierodula patellifera & 1 & - & - \\
\hline & \multirow[t]{3}{*}{ Diptera } & Tephritidae & & 1 & - & - \\
\hline & & Stratiomyidae & Hermetia illucens & - & 4 & - \\
\hline & & Calliphoridae & Chrysomya megacephala & - & - & 2 \\
\hline & \multirow[t]{2}{*}{ Odonata } & Aeshnidae & Rhinoaeschna sp. & 1 & - & - \\
\hline & & Libellulidae & Orthetrum sabina & 1 & - & - \\
\hline & \multirow[t]{14}{*}{ Coleoptera } & Scarabaeidae & Aphodius sp. & 1 & - & - \\
\hline & & & Haematonotus jenisi & - & - & 2 \\
\hline & & Curculionidae & Asymmathetes sp. & 3 & - & - \\
\hline & & & & - & - & 5 \\
\hline & & Silvanidae & & - & 2 & - \\
\hline & & Ptinidae & Lasioderma sp. & - & 1 & - \\
\hline & & Staphylinoidea & & - & 2 & 0 \\
\hline & & Chrysomelidae & Aulocophora similis & - & - & 4 \\
\hline & & Coccinellidae & $\begin{array}{l}\text { Coccinella } \\
\text { septempunctata }\end{array}$ & - & - & 6 \\
\hline & & & Coccinella transversalis & - & - & 5 \\
\hline & & & Harmonia octomaculata & - & - & 4 \\
\hline & & Carabidae & Pterostichus sp. & - & - & 2 \\
\hline & & & Stenolophus binotus & - & - & 2 \\
\hline & & Staphylinidae & Euconnus sp. & - & - & 1 \\
\hline \multirow[t]{2}{*}{ Diplopoda } & Julida & Julidae & Ommatoiulus sabulosus & - & - & 2 \\
\hline & Polydesmida & Paradoxosomatida & Anoplodesmu saussuriii & - & - & 1 \\
\hline \multirow[t]{4}{*}{ Aracnida } & \multirow[t]{4}{*}{ Araneae } & Sicariidae & Loxosceles reclusa & 5 & - & 2 \\
\hline & & Zodariidae & & - & 1 & 0 \\
\hline & & Lycosidae & & - & 1 & 0 \\
\hline & & Jumlah & & 115 & 53 & 108 \\
\hline
\end{tabular}

Keterangan: $\mathrm{KN}=$ kacang tanah; $\mathrm{KP}$ = kacang panjang; $\mathrm{KH}=$ kacang hijau; - = tidak ditemukan 


\section{Keanekaragaman Arthropoda}

Arthropoda yang diperoleh pada tiga lahan pertanian kacang mempunyai keanekaragaman jenis yang berbeda (Gambar 2). Jumlah individu jenis tertinggi adalah pada lahan kacang tanah, tetapi nilai keanekaragaman jenis serangga $\left(\mathrm{H}^{\prime}\right)$ tertinggi terdapat pada lahan kacang hijau sebesar 3,19. Indeks kekayaan jenis pada lahan pertanian kacang memiliki rentang 4,03-6,19. Nilai indeks tertinggi terdapat pada lahan kacang tanah sebesar 6,32 diikuti lahan kacang hijau sebesar 6,19, dan terendah adalah lahan kacang panjang sebesar 4,03 .

Hasil perhitungan indeks dominansi Arthropoda menunjukkan bahwa nilai D berada di antara 0,00 dan 0,50 sehingga tergolong rendah dan dapat dinyatakan di ketiga lahan pertanian kacang tidak ada jenis Arthropoda yang mendominasi (Gambar 2). Indeks kemerataan
Arthropoda di berbagai lahan pertanian kacang memiliki rentang nilai 0,82-0,94 (Gambar 2). Nilai indeks kemerataan dari tinggi ke rendah adalah lahan kacang hijau $(0,94)$, lahan kacang panjang $(0,86)$, dan lahan kacang tanah $(0,82)$.

Kisaran nilai $\mathrm{Cj}$ pada berbagai lahan pertanian kacang adalah 0,194-0,457 yang selanjutnya dikonversi ke persentase. Kesamaan Jaccard antar habitat kacang menunjukkan nilai lebih kecil dari $50 \%$ (Tabel 2) artinya tingkat kesamaan famili arthropoda yang ditemukan di ketiga habitat kacang tergolong rendah.

Tabel 2. Indeks Kesamaan Jaccard

\begin{tabular}{ccc}
\hline No & Lokasi & $\begin{array}{c}\text { Indeks Kesamaan } \\
\text { Jaccard }(\%)\end{array}$ \\
\hline 1 & KN \& KP & 23.08 \\
2 & KN \& KH & 45.71 \\
3 & KP \& KH & 19.35 \\
\hline
\end{tabular}

Keterangan: $\mathrm{KN}=$ kacang tanah; $\mathrm{KP}=$ kacang panjang; $\mathrm{KH}=$ kacang hijau

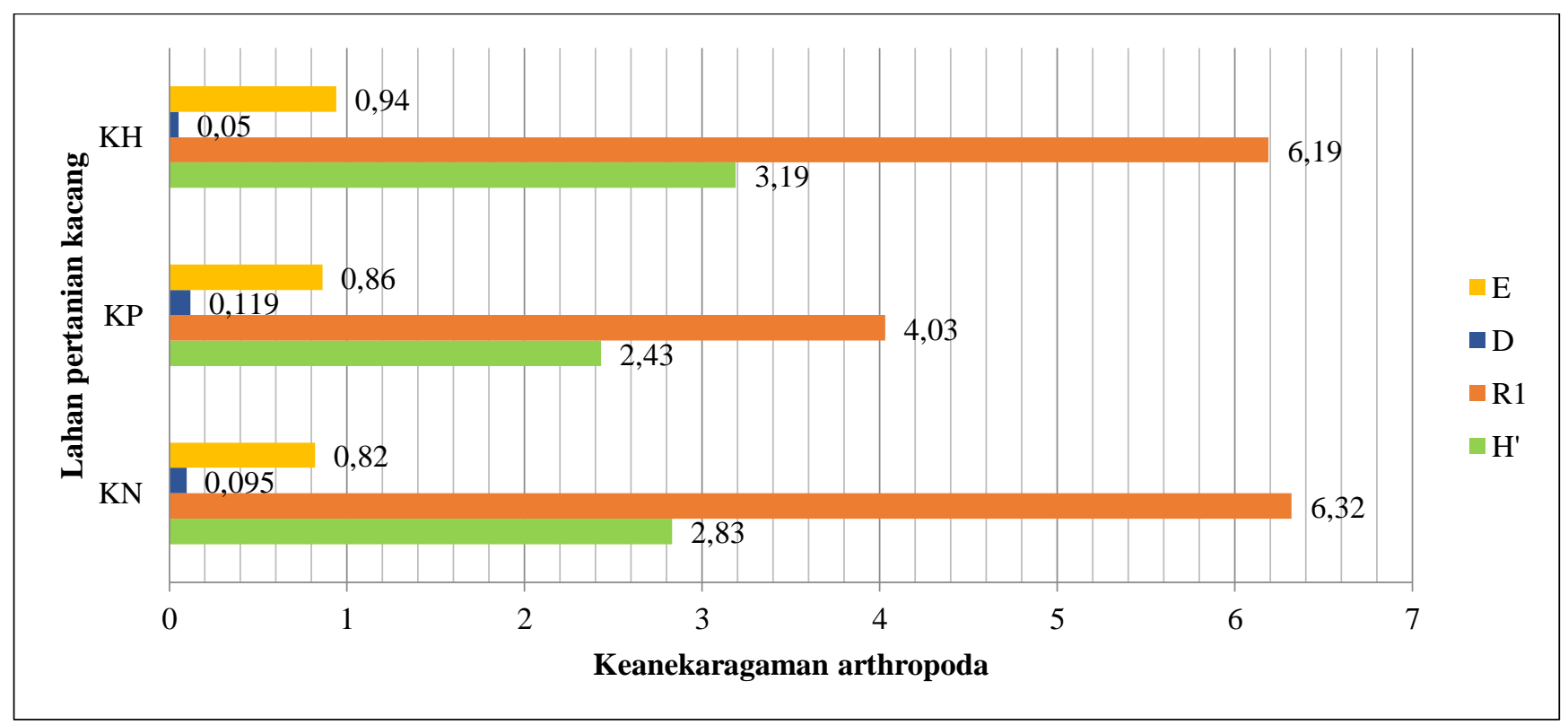

Gambar 2. Keanekaragaman Arthropoda di lahan pertanian kacang

Keterangan: $\mathrm{KN}=$ kacang tanah; $\mathrm{KP}=$ kacang panjang; $\mathrm{KH}=$ kacang hijau; $\mathrm{H}^{\prime}=$ Indeks diversitas ShannonWiener; R1 = Indeks kesamaan jenis; $\mathrm{D}=$ Indeks dominansi; $\mathrm{E}=$ Indeks kemerataan

\section{Faktor Abiotik}

Hasil yang diperoleh untuk faktor abiotik bervariasi untuk tiga lokasi penelitian (Tabel 3). Berdasarkan hasil analisis regersi linear berganda (Tabel 4) nilai korelasi (R) keanekaragaman dan kekayaan jenis secara berurut, yaitu sebesar $\mathbf{0 , 9 2 4}$ dan 0,813. Nilai korelasi ini tergolong sangat kuat (0.8-1). Dari output tersebut diperoleh koefisien determinasi ( $R$ Square) sebesar $\mathbf{0 , 8 5 4}$ dan $\mathbf{0 , 6 6 1}$ yang mengandung pengertian bahwa pengaruh faktor abiotik terhadap keanekaragaman Arthropoda sebesar 85,4\% dan 
66,1\%. Nilai F hitung sebesar 14,676 dan 4,867 dengan tingkat signifikansi sebesar $\mathbf{0 , 0 0 0}<\mathbf{0 , 0 5}$ dan $0,019<\mathbf{0 , 0 5}$. Hal ini memiliki arti faktor abiotik memberikan pengaruh yang siknifikan terhadap keanekaragaman dan kekayaan jenis Arthropoda yang ditemukan di tiga lahan kacang tersebut.

Tabel 3. Hasil pengukuran parameter abiotik

\begin{tabular}{clccc}
\hline No & \multicolumn{1}{c}{ Parameter abiotik } & $\begin{array}{c}\text { Lokasi } \\
\text { Desa Oematnunu } \\
\text { (Kacang tanah) }\end{array}$ & $\begin{array}{c}\text { Desa Mata Air } \\
\text { (Kacang Panjang) }\end{array}$ & $\begin{array}{c}\text { Desa Manusak } \\
\text { (Kacang Hijau) }\end{array}$ \\
\hline 1 & pH Tanah & 7.1 & 7.1 & 5.2 \\
2 & Suhu Tanah $\left({ }^{\circ} \mathrm{C}\right)$ & 31.8 & 30.6 & 31.4 \\
3 & Suhu Udara $\left({ }^{\circ} \mathrm{C}\right)$ & 32 & 30 & 31 \\
4 & Kelembaban tanah & Dry & Dry+ & Wet + \\
5 & Intensitas cahaya & Low & Low + & 24.4 \\
6 & Water Holding Capacity $(\mathrm{ml})$ & 42.6 & 59 & 2.16 \\
7 & Berat jenis tanah $\left(\mathrm{gram} / \mathrm{cm}^{3}\right)$ & 2.49 & 1.95 & 19.4 \\
\hline
\end{tabular}

Tabel 4. Output analisis regresi linear berganda pengaruh faktor abiotik terhadap keanekaragaman dan kekayaan jenis Arthropoda tanah

\begin{tabular}{lcccc}
\hline Faktor abiotik $\rightarrow$ keanekaragaman & R & R Square & F & Sig (o<0.05) \\
\hline$(\mathrm{pH}+$ suhu tanah+ WHC + berat jenis tanah) $\rightarrow$ H' & 0.924 & 0.854 & 14,676 & 0,000 \\
$(\mathrm{pH}+$ suhu tanah + WHC + berat jenis tanah) $\rightarrow \mathrm{R} 1$ & 0.813 & 0.661 & 4,867 & 0,019 \\
\hline
\end{tabular}

\section{PEMBAHASAN}

Di lahan pertanian kacang tanah Orthoptera merupakan ordo dengan jumlah famili dan spesies ditemukan terbanyak, yaitu 3 famili dan 13 spesies. Orthoptera merupakan ordo yang hidup pada lanskap yang bervariasi, memiliki kemampuan terbang yang menunjang daya jelajah wilayah baru (Ruchin \& Mikailenko, 2018). Ketiga famili dari Ordo Orthoptera yang ditemukan meliputi Gryllidae, Acrididae, dan Tettigoniidae. Acrididae (belalang) ditemukan dengan jumlah spesies terbanyak, yaitu 7 spesies. Belalang adalah jenis serangga Ordo Orthoptera dengan jumlah jenis mencapai 20.000 (Prakoso 2017). Sebagian anggota Orthoptera dikenal sebagai pemakan tumbuhan, namun ada beberapa di antaranya yang bertindak sebagai dekomposer, dan predator pada serangga lain. Belalang tergolong herbivora, terkadang menjadi hama pada tanaman serealia dan sayuran.
Belalang (Acrididae) berkumpul dalam jumlah jutaan di suatu lokus pertanian sehingga dapat menyebabkan kerusakan tanaman dalam skala yang besar (More \& Nikam 2016). Keanekaragaman belalang memiliki potensi yang kuat sebagai indikator kualitas baik tidaknya suatu ekosistem. Belalang memiliki asosiasi dengan karaktersitik vegetasi di habitat (Bazelet \& Samways, 2011). Famili Acrididae sering menimbulkan permasalahan di ekosistem pertanian ketika berperan sebagai hama (Semiun \& Mamulak, 2019). Kumar and Usmani (2014) menyatakan bahwa belalang tersebar luas di semua sistem ekologi dengan kepentingan ekonomi yang signifikan karena perannya yang merusak bagi hampir semua jenis vegetasi hijau. Di lahan pertanian kacang potensi sebagai hama dari jenis belalang ini tidak nampak karena jumlahnya yang sedikit.

Pada lahan pertanian kacang panjang ditemukan Ordo Hymenoptera dengan jumlah 
spesies terbanyak, yaitu 5 spesies. Hymenoptera mencakup tawon, lebah, dan semut. Menurut Aguiar et al. (2013), Hymenoptera merupakan salah satu ordo serangga yang paling banyak spesiesnya setelah Coleoptera dan Lepidoptera. Hymenoptera dibagi ke dalam dua subordo (Symphyta dan Apocrita), dengan 27 super famili (9 superfamilies di Symphyta dan 18 di Apocrita) dan 132 famili, salah satunya Famili Formicidae (semut). Semut merupakan kelompok serangga yang paling dominan di daerah terestrial terkait dengan kebiasaan makan yang beragam. Semutsemut ini secara tidak langsung berperan dalam menjaga kesuburan tanah dengan cara mengurai bahan organik menjadi butiran yang lebih kecil, dan memelihara ruang pori tanah melalui lubanglubang yang dibuat oleh koloni semut di dalam tanah. Semut membangun sarang di lubanglubang tanah untuk pemeliharaan keturunan dan menyimpan bahan makanan (Borror et al. 1992).

Di lahan pertanian kacang hijau didapati kelas Diplopoda yang tidak ditemukan di dua lahan pertanian kacang lainnya. Diplopoda (kaki seribu) merupakan kelompok organisme darat yang paling beragam, dengan lebih dari 12.000 spesies teridentifikasi (Siewarld \& Bond 2007). Famili Pyrgomorphidae adalah jenis belalang yang paling banyak ditemukan. Pada penelitian ini ditemukan tiga jenis yaitu Atractomorpha crenulata, Atractomorpha sinensis, dan Atractomorpha sp. Pyrogomorphidae hidup pada daerah tropis dan subtropis. Pyrgomorphidae merupakan salah satu famili dari superfamili Acridoidea. Pyrgomorphidae hanya memiliki satu subfamili Pyrgomorphinae yang terdiri dari 29 genus, dan sekitar 400 jenis telah diidentifikasi (Seino \& Njoya, 2018). Adanya area ekologis pada kawasan pertanian akan meningkatkan area distribusi dari belalang pada satu wilayah (Sugiarto, 2018).

Keanekaragaman jenis Arthropoda yang diperoleh pada tiga lahan pertanian kacang bervariasi. Jumlah individu jenis tertinggi adalah pada lahan kacang tanah, tetapi nilai keanekaragaman jenis serangga $\left(H^{\prime}\right)$ tertinggi terdapat pada lahan kacang hijau. Pada lahan kacang tanah, tingginya jumlah morfospesies dan individu serangga tidak diikuti dengan tingginya nilai indeks keanekaragaman jenis Shannonwiener. Hal ini dikarenakan terdapat satu jenis yang yang memiliki jumlah yang relitif lebih banya dari spesies Arthropoda lainnya yaitu Mymicra rubra. Menurut Ludwig dan Reynolds (1988), H' maksimum hanya ketika semua spesies (jumlah total spesies dalam komunitas) diwakili oleh jumlah individu yang sama, yang merupakan distribusi kelimpahan yang sempurna.

Arthropoda tanah secara langsung maupun tidak langsung memberikan pengaruh terhadap vegetasi di atasnya. Oleh karena itu, keanekaragaman vegetasi akan menentukan keanekaragaman artrhropoda tanah. Beberapa arthropoda spesifik untuk habitat tertentu bergantung pada aktivitas maksimum bersarang, kawin, dan ketersediaan makanan (Zayadi et al. 2013). Selanjutnya, Esenowo et al. (2014) melaporkan bahwa karakteristik tanah dapat mempengaruhi kelimpahan dan keanekaragaman Arthropoda tanah di lahan pertanian.

Indeks kekayaan jenis Arthropoda di lahan kacang-kacangan kabupaten kupang tergolong sedang sampai tinggi. Tinggi rendahnya kekayaan Arthropoda di pengaruhi oleh adanya sumber makan dan iklim. Sumber makan bagi Arthropoda dapat diperoleh dari tanaman kacang dan juga tanaman budidaya yang berada di sekitar lahan pertanian kacang seperti padi, gamal, pisang, asam, dan lontar. Kabupaten Kupang pada umumnya beriklim tropis dengan curah hujan yang relatif rendah (https://kupangkab.go.id), hal ini diduga berpengaruh terhadap keanekaragam Arthropoda pada lahan pertanian kacang. Hasil perhitungan indeks dominansi Arthropoda tergolong rendah dan dapat dinyatakan di ketiga lahan pertanian kacang tidak ada jenis Arthropoda yang mendominasi. Nilai dominansi jenis yang ada tidak menunjukkan adanya pemusatan dominansi pada jenis tertentu, maka indeks dominansi spesies menjadi rendah. Sebaliknya, jika terjadi pemusatan dominansi pada jenis tertentu maka indeks dominansinya menjadi tinggi. 
Nilai kemerataan (E) yang mendekati satu menunjukan bahwa suatu komunitas semakin merata penyebarannya (Magurran 2004) dan menunjukan sumber daya alami pendukung kehidupan merata pada semua lahan pertanian kacang. Semakin kecil nilai E, semakin kecil pula keseragaman populasi, artinya penyebaran jumlah individu setiap jenis tidaklah sama dan ada kecenderungan satu jumlah individu yang mendominasi, begitu pula sebaliknya semakin besar nilai E maka tidak ada jenis individu yang mendominasi (Annam \& Khasanah 2017). Perbedaan nilai kemerataan dapat menunjukan spesies dengan jumlah individu yang tinggi atau adanya rentang nilai antar jumlah individu pada masing-masing spesies yang cukup jauh.

Pada penelitian ini menggunakan data famili dalam menganalisis indeks kesamaan Jaccard. Kisaran nilai $\mathrm{Cj}$ pada berbagai lahan pertanian kacang adalah 0,194-0,457. Apabila mendekati nilai 1 menujukkan tingkat kesamaan jenis antar habitat tinggi, dan apabila mendekati nilai 0 menunjukkan tingkat kesamaan jenis antar habitat rendah. Dalam menggambarkan nilai $\mathrm{Cj}$ dari ketiga habitat kacang tersebut, maka angka yang telah diperoleh dikonversi ke persentase. Kesamaan Jaccard antar habitat kacang menunjukkan nilai lebih kecil dari 50\%, artinya tingkat kesamaan famili Arthropoda yang ditemukan di ketiga habitat kacang tergolong rendah.

Suhu merupakan salah satu faktor fisika yang menentukan kehadiran dan kepadatan organisme tanah, karena menentukan tingkat dekomposisi material organik tanah (Suin 2012). Suhu tanah pada ketiga lokasi lahan kacang berada pada kisaran $30,6^{\circ} \mathrm{C}-31,8^{\circ} \mathrm{C}$. Sedangkan suhu udara berada pada kisaran $30{ }^{\circ} \mathrm{C}-32{ }^{\circ} \mathrm{C}$. Fluktuasi suhu tanah lebih rendah dari suhu udara, sehingga suhu tanah sangat tergantung dari suhu udara. Suhu tanah lapisan atas mengalami fluktuasi dalam satu hari satu malam tergantung musim. Fluktuasi juga tergantung pada keadaan cuaca, topografi daerah dan keadaan tanah. Suhu tanah dipengaruhi oleh intensitas cahaya matahari, semakin rendah intensitas cahaya maka suhu tanah semakin rendah (Suin 2012).

Water holding capacity atau kapasitas tanah menahan air dalam penelitian ini memiliki kisaran nilai $24,4 \mathrm{ml}$ - $59 \mathrm{ml}$. Lahan kacang panjang memiliki nilai WHC tertinggi sebesar $59 \mathrm{ml}$, diikuti lahan kacang tanah sebesar 42,6 ml, dan terendah lahan kacang hijau sebesar 24,4 ml. Walaupun di lahan kacang tanah tidak mengunakan aplikasi pestisida, pupuk, dan air, nilai WHCnya tergolong tinggi. Lahan kacang hijau menunjukan nilai WHC terendah. Pada lahan tersebut tekstur tanahnya agak kasar dan berpasir. Tekstur tanah yang baik membuat kandungan bahan organic semakin tinggi sehinngga akan meningkatkan kapasistas menahan air (Semiun \& Stanis 2016). Harist et al. (2017) menyatakan bahwa kapasitas menahan air juga berhubungan erat dengan porositas tanah, jika porositas tanah tinggi maka kemampuan tanah menahan air akan tinggi.

Hasil pengukuran $\mathrm{pH}$ tanah dalam penelitian ini yaitu memiliki kisaran antara 5,2 sampai 7,1. Pengukuran $\mathrm{pH}$ sangat penting dalam ekologi hewan tanah karena keberadaan dan kepadatan hewan tanah sangat tergantung pada $\mathrm{pH}$ tanah. Perbedaan $\mathrm{pH}$ memungkinkan adanya perbedaan keanekaragaman dan komposisi Hal ini berarti dengan nilai $\mathrm{pH}$ tanah yang menurun maka akan sangat berpengaruh terhadap keanekaragaman di mana keanekaragaman cenderung juga akan menurun. Menurut Riyanto et al. (2007) kisaran $\mathrm{pH}$ 4,5-7 merupakan kisaran umum untuk kebanyakan makhluk hidup. Muli et al. (2015) melaporkan bahwa kisaran $\mathrm{pH}$ 3.50-6.60 masih dapat mendukung kehidupan Arthropoda tanah. Selanjutnya, Suin (2012) menjelaskan bahwa terdapat fauna tanah yang dapat hidup di kondisi $\mathrm{pH}$ asam dan dapat dijumpai pula pada kondisi $\mathrm{pH}$ basah.

Intensitas cahaya di ketiga lahan kacang tergolong rendah dan sangat rendah. Intensitas cahaya di lahan pertanian tergolong sangat rendah, hal ini dikarenakan di sekitar lahan terdapat pohon-pohon besar yang menghalangi masuknya cahaya matahari. Adebuntan (2007) 
dalam Esenowo et al. (2014) melaporkan bahwa keanekaragaman Arthropoda yang tinggi umumnya ditemukan ketika ada penetrasi cahaya, serasah daun, dan tanah berbatu. Invertebrata tanah memainkan bagian integral dalam fungsi ekosistem tanah dan menyediakan layanan ekosistem seperti penguraian, siklus unsur hara, penekanan hama, dan bioremediasi tanah. Sifat fisik tanah yang menentukan kualitas tanah adalah berat jenis tanah. Berat jenis tanah berkaitan dengan bahan organik tanah. Bahan organik tanah dibutuhkan oleh Arthropoda untuk melakukan aktivitas fosiologis.

\section{SIMPULAN}

Keanekaragaman jenis Arthropoda tertinggi ditemukan pada lahan pertanian kacang hijau, sedangkan kekayaan jenis tertinggi terdapat pada lahan kacang tanah. Tidak ada jenis Arthropoda yang mendominasi di ketiga lahan pertanian kacang dengan kemerataan jenis tergolong merata penyebarannya. Tingkat kesamaan famili Arthropoda yang ditemukan di ketiga habitat kacang tergolong rendah. Selanjutnya, faktor abiotik memberikan pengaruh yang signifikan terhadap keanekaragaman arthropoda.

\section{UCAPAN TERIMA KASIH}

Terima kasih kepada Kementerian Riset, Teknologi dan Pendidikan Tinggi Direktorat Jenderal Penguatan Riset dan Pengembangan yang telah memberikan bantuan dana hibah penelitian dosen pemula periode tahun 2019. Kepada mahasiswa program studi Biologi FMIPA Universitas Katolik Widya Mandira yang terlibat dalam mensukseskan penelitan ini.

\section{KEPUSTAKAAN}

Aguiar PA, Deans RA, Engel SM, Forshage M, Huber TJ, Jennings TJ, Johnson FN. 2013. Ordo hymenoptera. In: Zhang, Z-Q (Ed) animal biodiversity: an outline of higherlevel classification and survey of taxonomic richness (Addenda 2013). Zootaxa 1: 51-62.
Amin A, Ibrohim I, Tuarita H. 2016. Studi keanekaragaman Arthropoda pada lahan pertanian tumpangsari untuk inventarisasi predator pengendalian hayati di Kecamatan Bumiaji Kota Batu. Jurnal Pertanian Tropik 3(2): 139-149

Annam AC, Khasanah N. 2017. Keanekaragaman Arthropoda pada pertanaman kubis (Brassica oleracea L.) yang diaplikasi insektisida kimia dan nabati. Agrotekbis 5(3): 308-314.

Ardillah JS, Leksono AS, Hakim L. 2014. Diversitas Arhropoda tanah di area restorasi Ranu Pani Kabupaten Lumajang. Biotropika: Journal of Tropica Biology 2(4): 208-213.

Bazelet CS, Samways MJ. 2011. Identifying grasshopper bioindicators for habitat quality assessment of ecological networks. Ecological Indikator 11(5): 1259-1269.

Borror D, Triplehorn CA, Johnson NF. 1992. Pengenalan Pelajaran Serangga Edisi Keenam. Universitas Gadjah Mada: Yogyakarta.

Culliney WT. 2013. Review: Role of Arthropods in Maintaining Soil Fertility. Agriculture 3: 629-659.

Elhayati N, Hariri AM, Wibowo L, Fitriana Y. 2017. Keanekaragaman Arthropoda permukaan tanah pada pertanaman ubi kayu (Manihot utilissima Pohl.) setelah perlakuan olah tanam dan pengelolaan gulma. $J$. Argotek Tropika 5(3):158-164.

Esenowo IK, Akpabio EE, Adeyemi-Ale OA, Okoh VS. 2014. Evaluation of arthropod diversity and abundance in contrasting habitat, uyo, akwa ibom state, Nigeria. $J$. Appl. Sci. Environ. Manage 18(3): 403-408.

Haneda N, Kusmana C, Kusuma F. 2013. Keanekaragaman serangga di ekosistem mangrove. Jurnal Silvikultur Tropika, 4(1): 42-46.

Harist A, Wawan, Wardati. 2017. Sifat fisik tanah dan pertumbuhan tanaman karet (Hevea brasiliensis Muell. Arg) pada beberapa kondisi penutupan lahan dengan Mucuna bracteata. JOM Faperta UR 4(2):1-14.

Kumar H, Usmani MK. 2014. Taxonomic studies on Acrididae (Orthoptera: Acridoidea) from Rajasthan (India). Journal of Entomology and Zoology Studies 2(3): 131-146. 
Ludwig JA, Reynolds JF. 1988. Statistical Ecology: A Primer methods and computing. JohnWiley \& Sons: New York.

Magurran AE. 2004. Measuring Biological Diversity. Blackwell Science Ltd

More SV, Nikam KN. 2016. Studies grasshoppers (orthoptera) in tilari forest, Chandgad, Kolhapur district of Maharashtra (India). International Journal of Recent Scientific Research (IJRSR) 7(3): 9457-9460.

Muli R, Irsan C, Suheryanto. 2015. Komunitas Athropoda tanah di kawasan sumur minyak bumi di desa Mangunjaya, kecamatan Babat Toman, kabupaten Musi Banyuasin, provinsi Sumatera Selatan. Jurnal Ilmu Lingkungan 13(1): 1-11.

Parmar TK, Rawtani D, Agrawal YK. 2016. Bioindicators: the natural indicator of environmental pollution. Frontiers in Life Science 9(2): 110-118.

Prakoso, B. 2017. Biodiversitas belalang (acrididae: ordo orthoptera) pada agroekosistem (Zea mays L.) dan ekosistem hutan tanaman di Kebun Raya Baturaden, Banyumas. Biosfera 34( 2): 80-88.

Riyanto. 2007. Kepadatan, pola distribusi dan peranan semut pada tanaman di sekitar lingkungan tempat tinggal. Jurnal Penelitian Sains 10(2): 241-253.

Ruchin BA, Mikhailenko PA. 2018. Fauna of mantids and orthopterans (Insecta: Mantodea, Orthoptera) of the Mordovia State Reserve, Russia. Biodiversitas 19(4): 11941206.

Seino RA, Njoya MTM. 2018. Species diversity of pyrgomorphidae (orthoptera: caelifera) grasshoppers in the north west region of Cameroon. International Journal of Zoology and Applied Biosciences 3(1): 104-109.

Semiun CG, Mamulak YI. 2019. Keanekaragaman jenis belalang (Ordo Orthoptera) di pertanian kacang hijau (Vigna radiate L.) desa Manusak kabupaten Kupang. Stigma 12(2): 66-70.

Semun CG, Lengur ERA, Duhan GUUB. 2020. Insect diversity profile of mangrove ecosystem in Menipo Nature Tourism Park, East Amarasi, East Nusa Tenggara. IOP Conference Series: Materials Science and Engineering 823: 1-9.
Semiun CG, Stanis S. 2016. Kelimpahan dan keanekaragaman Arthropoda tanah pada lahan pertanian monokultur dan polikultur di desa Labat Kupang. BioWallacea Jurnal Ilmiah Ilmu Biologi 2(3): 154-161.

Sierwald P, Bond JE. 2007. Current Status of the Myriapod Class Diplopoda (Millipedes): Taxonomic Diversity and Phylogeny. Annual Review of Entomology 52(1): 401-420.

Sugiarto A. 2018. Inventarisasi belalang (Orthoptera: Acrididae) di perkebunan dan persawahan Desa Serdang Menang, Kecamatan Sirah Pulau Padang, Kabupaten Ogan Komering Ilir.Insect Village 1(3): 7-10.

Suin MN. 2012. Ekologi Hewan Tanah. Bandung: Bumi Aksara.

Zayadi H, Hakim L, Leksono AS. 2013. Composition and diversity of soil arthropods of Rajagwesi Meru Betiri Natinal Park. The Journal of Tropical Life Science 3(3): 166171. 